\title{
Role of Indian Youth in Keeping COVID-19 at Bay : A Narrative Review
}

\author{
Shraddha Kalyani*, Rushi Somani \\ Department of Pharmaceutics, Govt. Collage of Pharmacy, Karad (Satara), Maharashtra, India
}

\begin{abstract}
A pandemic is defined as "an epidemic occurring worldwide, or over a very wide area, crossing international boundaries and usually affecting a large number of people". The classical definition includes nothing about population immunity, virology or disease severity. As World Health Organization declared COVID-19 as pandemic in very beginning of year 2020. In COVID-19 CO stands for corona, 'VI' for virus, and 'D' for disease. Formerly, this disease was referred to as '2019 novel coronavirus' or '2019-nCoV.' The COVID-19 virus is a new virus linked to the same family of viruses as Severe Acute Respiratory Syndrome (SARS) and some types of common cold. First case in India was detected in the last week of January 2020. As India is second largest country in terms of population with less geographical area and COVID-19 is contagious infection disease it's going to affect large population in India and affect different sectors such as specially health and financial sector. According to '2011 Census of India' in India by next 10 years from 2011 number of young people will be more, that's why what youngsters do in such situation will define our country's future.
\end{abstract}

Keywords : Pandemic, Lifestyle, Youth, Digitalization, Opportunities.

\section{INTRODUCTION}

Lockdown- The only solution we all have during this pandemic but is it a 'Solution'??? of course Not. Being at home and doing nothing or binge-watching your favorite series on Netflix or Video calling your old school gang or cooking and baking something new every day, how much one can sustain with all of it? Hardly a few weeks or months but what's next? Is every Indian celebrating the lockdown like this? Of course Not, then what's next plan??? How one can especially youth can work either to get all these things to normal or to make ourselves easy to live with Corona.

Before discussing 'Role of Indian Youth in Keeping Covid-19 at bay' first thing we have to do is, let's accept the fact that we have to live our life with Covid-19 in future times and then be serious about the responsibilities we have as Indian citizen while day to day routine. For better understanding, I will differentiate some of my ideas into 5 parts; let's call it as 'Panchsutri Yojana'

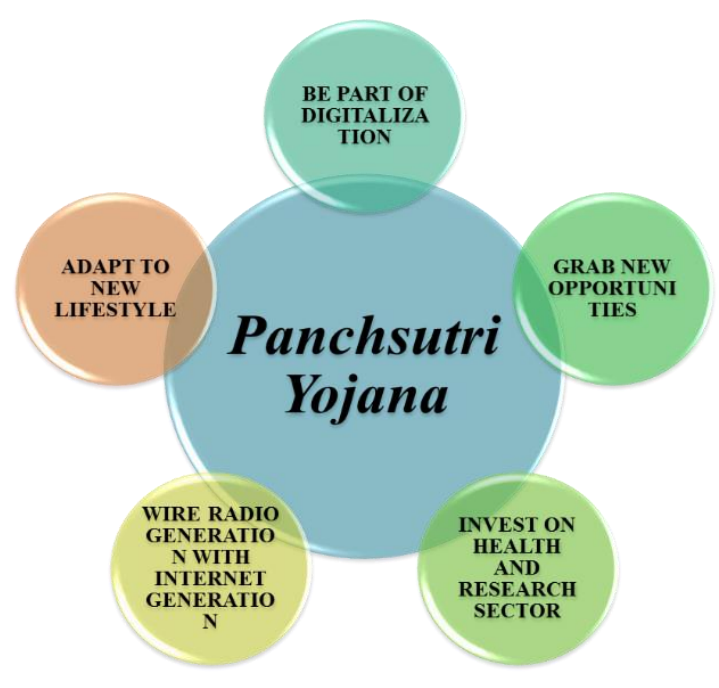


1. Be part of digitalization-In today's time of lockdown where all schools and colleges are closed, business is almost collapsed something is still there which gives you a ray of hope, isn't it a good experience to learn something from your expert teachers though all of us are miles away or taking home delivery of fresh Mangoes in this summer season, yes it is. Then what's that which makes all this possible yes it's part of Digitalization where traditional offline classes turn into online lectures, seminars are converted to webinars, round table meetings converted to zoom meeting all these things proved that this is right time accept change and cope up with it. After this lockdown will over but one must understand the importance of digitalization though it starts with small things like paying your online light bill or just attending an interview over Skype to convert your shop into an online shopping site. All will change gradually but as part of Indian Youth, we must spread this change all over just not limit it to metro cities. It should be absorbed until the very last person in rural India. Because this is the demand of time. I agree it will take time but youth should lead this with a moto as it is always said that 'Journey of thousand miles starts with small steps'.

2. Grab new opportunities- We all know that when the whole world was complaining about the lockdown and posting it on Facebook, the true businessman was convincing that Facebook founder to invest in his company, and now it will be known as the largest investment in any company. So just not waste your day rather wake up and work on your ideas. When India is dreaming to be a 'Aatmanirbhar' which will open gateway for many new innovative business ideas, why not bring your ideas on the table and grab this opportunity. This is the perfect time for Indian youth just 'Eat local and think Global'. The second most important thing the youth should look into is, due to this lockdown the migration of many workers has been done, which will hamper on an industrial area as well as a small business but the other hand, it will also create new options of bread and butter to local workers especially youth. So now let's not just complain that they had grabbed your employment instead use this opportunity to create a new one because 'In the middle of difficulty lies the opportunity'.

\section{Invest in the health and research sector-}

Covid-19 is a wake-up call for all of us, as individuals, as a society, as Nation. Life after this pandemic will not- and should not -be the same. We as a developing country should rethink our priorities. Indian youth can lead this by involving more in the improvement of health education in society. All basic infrastructure of primary health clinics should be built in future times in every part of rural India and it should be maintained periodically. Also, special care should be taken for infectious diseases.

One more thing which comes in the light during this pandemic is the need for health insurance. In India, people are not much interested to buy health insurance. It is high time to think about it as it can give you a better medical treatment even during the financial crisis and we as youth think about it.' Do something today that your future self will thank you for.'

Today everyone is waiting for a vaccine to come as magic and vanishes off the disease, is it that easy? No. Single new drug moiety has to travel almost 10-12 years to come at your Pharmacy counter along with the efforts of hundreds of researchers and expenditure of billions of rupees. But today we expect to find out the vaccine on the very next day of a pandemic. Just ask one question to our self that, how much we invest in the research sector in terms of money, infrastructure, and human resources? I am sure your answers are not that satisfying. But in future time we should think about it, as youth engagement in the basic science research should be more. We must promote this with 
the availability of infrastructure and funds. As it is famously said that 'Hours of research work can cut the months of fieldwork'.

\section{Wire the radio generation with the internet} generation- Youth is the amalgamation of the best of both the worlds. It is a carrier of the old generation's belief and adaptor of millennial's flamboyant implementation. As youth one should fill this generation gap and help both this world to make a move in this pandemic. It may start with small actions like teaching how to do online transactions to your father or how to mimic a practical demo at home by watching online tuitions to your son. We as youth have to do all this in future times as the definition of living will change.

Today we all are talking about social distancing but if you carefully see all this, one thing you may understand that we are not socially distanced. We are still learning from our professor while sitting at home, we can still talk to our school friend who is living in a different country or we can still share the gossips with our college gang who are in different cities of a nation then where is the question of social distancing, rather we should call it as 'physical distancing'. This distancing may change our way of living but will not change our zeal of living.

5. Adapt to new lifestyle- As said earlier the postpandemic world will have different ways of living. The definition of joy will change. The mode of traveling will change. The source of earning may change. Let's discuss it one by one. Hygiene and meditation are two important terms which are newly defined in this period, one which is important for physical well-being and second is for mental well-being. Along with proper diet and exercise, we must take care of good physical and mental health. Not only in youth but we should promote the importance of this to all generations. Because many people may find difficulties to adapt to this new world. As the said earlier definition of joy will change, People instead of going to the cinema hall and watching their favorite movie will now prefer to seat in-homes living area and watch their favorite movie or web series. This era of the web may open a new platform for many youngsters. Instead of hanging out in malls, people will prefer online shopping which again gives a great platform to many new ideas of ready to eat food or home delivery services. The most hampered sector in the postpandemic world will be tourism. So, here we can promote local tourism and explore more about Indian heritage. Along with traditional business income sources, youngsters must think about secondary income sources. Because unfortunately if such a situation of lockdown comes again in the future, we must have a secondary income source to fulfill daily needs. It may be in forms of share market or real estate or the world of digital marketing.

Here I am not claiming that this 'Panchsutri Yojana' will destroy the Covid-19, but surely it will help every Indian to live peacefully in the postpandemic world. It will help to follow the rules of physical distancing. It helps spread the importance of health and hygiene among Indians. Along with it, it will surely open new doors of employment and startups. The feeling of one whole family will take all generations together for better India after postpandemic times. We as responsible youth should participate in this making of new India. So, let's be a ray of sunshine on this rainy day and keep Covid-19 at bay.

\section{REFERENCES}

1. Harapan Harapana,b,c, Naoya Itohd, Amanda Yufikae, Wira Winardif, Synat Keamg, Haypheng Teh, Dewi Megawatii,j, Zinatul Hayatia,b,c,k, Abram L. Wagnerl, Mudatsir Mudatsir, Coronavirus disease 2019 (COVID-19): A literature review, 
Journal of Infection and Public Health, 13 (2020) $667-673$

2. Riyanti Djalante, Jonatan Lassa, Davin Setiamarga, Aruminingsih Sudjatma, Mochamad Indrawan, Budi Haryanto, Choirul Mahfud, Muhammad Sabaruddin Sinapoy, Susanti Djalante, Irina Rafliana, Lalu Adi Gunawan, Gusti Ayu Ketut Surtiari, Henny Warsilah, Review and analysis of current responses to COVID-19 in Indonesia: Period of January to March 2020, Progress in Disaster Science 6 (2020) 100091.

3. Said Nadeem, Coronavirus COVID-19: Available Free Literature Provided by Various Companies, Journals and Organizations around the World, J Ong Chem Res, 2020, 5(1): 7-13, Document ID: 2020JOCR37, doi:10.5281/zenodo.3722904.

4. Francesco Di Gennaro, Damiano Pizzol, Claudia Marotta, Mario Antunes, Vincenzo Racalbuto, Nicola Veronese and Lee Smith, Coronavirus Diseases (COVID-19) Current Status and Future Perspectives: A Narrative Review, Int. J. Environ. Res. Public Health 2020, 17, 2690; doi:10.3390/ijerph17082690.

5. Xu Qian, Ran Ren, Youfa Wang, Yan Guo, Jing Fang, Zhong-Dao Wu, Pei-Long Liu, Tie-Ru Han and Members of Steering Committee, Society of Global Health, Chinese Preventive Medicine Association, Fighting against the common enemy of COVID-19: a practice of building a community with a shared future for mankind, Qian et al. Infectious Diseases of Poverty (2020) 9:34

6. Yan-Rong Guo, Qing-Dong Cao, Zhong-Si Hong, Yuan-Yang Tan, Shou-Deng Chen, Hong-Jun Jin, Kai-Sen Tan, De-Yun Wang and Yan Yan, The origin, transmission and clinical therapies on coronavirus disease 2019 (COVID-19) outbreak - an update on the status, Guo et al. Military Medical Research (2020) 7:11

7. https://www.who.int/

8. https://www.who.int/emergencies/diseases/novelcoronavirus-

2019? gclid=Cj0KCQjwrIf3BRD1ARIsAMuugNt3n 5daPU1Pt0fhEqSi7-

y2_U5H7j_4yOihsIcS6Uj1JJmwXqv-IqEaAi-

vEALw_wcB

9. https://www.who.int/news-room/detail/27-04-2020who-timeline---covid-19

10. https://censusindia.gov.in/pca/cdb_pca_census/cd_b lock.html

11. https://www.mygov.in/covid-19

12. https://en.wikipedia.org/wiki/COVID19_pandemic_in_India

\section{Cite this article as :}

Shraddha Kalyani, Rushi Somani, " Role of Indian Youth in Keeping COVID - 19 at Bay : A Narrative Review", International Journal of Scientific Research in Science and Technology (IJSRST), Online ISSN : 2395-602X, Print ISSN : 2395-6011, Volume 7 Issue 3, pp. 357-360, May-June 2020. Available at doi : https://doi.org/10.32628/IJSRST207365 Journal URL : http://ijsrst.com/IJSRST207365 